\title{
Women and Industry in Taiwan
}

\author{
NORMA DIAMOND \\ University of Michigan
}

One of the factors underlying Taiwan's industrial growth over the past two decades has been the availability of a pool of underemployed, young workers who will accept relatively low wages, who are unlikely to raise demands for higher pay, shorter hours, or seniority benefits and who, in many instances, expect only short-term employment. Women are a significant segment of this industrial work force. By the start of the 1970s, at least $20 \%$ of the employed population over the age of 15 was engaged in manufacturing. Of these, $33 \%$ were women, most of whom were between the ages of 15 and 25 (Taiwan Provincial Labor Force Survey and Research Institute, 1971). While their male counterparts, also relatively young, held an expectation of continuous employment, increased skill-learning and job advancement within the factory workplace, the women workers were more likely to see their jobs as a brief interim between school and marriage (Kung, 1976).

A major concern in my research is the effect of outside employment on women's status, autonomy, and control over their future and present lives. There is a fairly simplistic model of women's liberation in circulation which assumes that increased participation in the work force by women will modify or radically change their position within their natal households and give them the power to shape their future lives. There is no question that

MODERN CHINA, Vol. S, No. 3, July 1979 317-340

() 1979 Sage Publications, Inc. 
the passing of "traditional society" (i.e., peasant society) and the rise of capitalist, industrial society does generate legal and social changes which enhance women's status. In Taiwan, as elsewhere, women have received the right to own property, the right to seek divorce, the right to vote and to stand for election to public office, access to at least a primary school education, and of course the increased opportunity to work outside the domestic sphere. Changing social mores have raised the age at which people expect to marry, and young people are allowed more of a choice in that decision. Emulation of American and Japanese lifestyles, reinforced by media presentation, has affected many things, from fashions and cosmetics to family form and recreational activities.

However, it would be a mistake to attribute these various changes to the fact that young women now work in factories and shops rather than on the family farm. Most of these changes, if not all; originate in the upper classes and filter down to the working class. They are part of bourgeois culture, and to the extent that they benefit women, working-class women will to some degree share in those benefits. But as this article hopes to demonstrate, women working in the factories (and, by extension, in other similar low-paid, low-skill jobs) have neither power within the household nor real control over their lives in the ways that earlier writers have suggested (Fei, 1939; Lamson, 1931; Lang, 1946). On the contrary, in the Taiwan case women's wages usually remain under the control of the household head, and women's work, whether inside the household or outside in the shops and factories, is defined as an extension of their familial duties. Women work as members of households, not as individuals. For many, the situation is little different from the past when women contributed to household income by home weaving and spinning, or participation in agricultural work as was somewhat the case in southern Taiwan.

The most notable difference between the present and the past is that young girls now have more visible value to their families. They are useful wage earners at an age when their 
brothers are still students, low-paid soldiers (to whom the family often sends money), or unpaid craft apprentices. Girls' refusals of an early engagement meet with acquiescence and small sighs of relief from families who look forward to a continuation of their daughters' earnings. One hears less about "useless daughters": whatever the initial costs of raising a daughter might be, they are repaid during the five to ten years that she will work outside. With careful management some of the daughter's earnings can be applied toward her dowry, enhancing her marriage opportunities, and giving the family additional prestige. But none of this should be confused with the issues of independence or power for working girls.

The data in this article, and some of the generalizations I am making, come from a set of interviews with women textile workers in Tainan City in $1970 .^{1}$ In some ways, the situation of these young women workers of the late twentieth century resembles that of the female workers in factories in the United States and England during the late nineteenth and early twentieth centuries. We are dealing with a period in which there is heavy migration from the rural to the urban areas, a decline in the actual numbers as well as in the proportion of the work force engaged in agriculture, a decline in the prevalence of smallscale handicraft enterprises, and the rise of a new middle class and working class. In many households, daughters are the first in the family to enter the modern sector. Women are, in fact, actively recruited and encouraged into industry by factory representatives who go out to the rural schools, and families are eager for them to take advantage of these new opportunities.

Yet it is clear that women enter industry on a different basis than men. For both local entrepreneurs, and for foreign industry seeking the advantages of Taiwan's low-cost labor supply, women are ideal workers in that neither they nor anybody else considers it necessary or desirable that they receive an independent wage. Few receive earnings that would adequately meet living costs and present-day consumer expectations for a single individual living on her own, let alone sufficient wages to support a household. Most women workers are unmarried and either live at 
home, thus saving on the cost of bed and board at no expense to the employer, or they are accommodated in factory dormitories under spartan conditions at little cost to the employer. There is no social support for the idea of working girls having an apartment together, free of adult supervision. Certainly it is cheaper for employers than providing salaries which would cover the single worker's rent. On the other hand, many factories provide simple meals, subsidizing part of the cost, for their live-in workers, which is a fringe benefit or hidden wage. Still, women workers cost less than males who over time expect and require wages high enough to support not only themselves but also a wife and children, and who in addition require enough to maintain a separate household and/or contribute to the maintenance of aging parents.

What becomes of the girls' wages? The answer to that question is that the earnings of unmarried daughters are usually remitted to parents to supplement the budget of the larger household, with some portion retained as pocket money. The latter sum usually increases in amount, if not proportion of total earnings, over the years that the girl spends in the factory. There is, of course, some hope of higher wages, sought by transferring to another factory where one has heard one can earn a bit more. Nevertheless, and this is particularly true for the youngest workers, the basic attitude is that whatever money one can hold over and beyond the costs of bare subsistence is a windfall for which one ought to be grateful. This first generation of proletarians is a very filial one, and repayment to parents an unavoidable obligation.

There are a few other generalizations to be made at this juncture, which flow from the age range of Taiwan's industrial work force. As indicated earlier, some $75 \%$ of factory women fall between the ages of 15 and 24 . Some are younger, although it is technically illegal to hire below age 15 . Few are older because most factories will not hire married women or allow their women workers to continue employment after marriage. The same holds true for many clerical and sales jobs as well. For most female workers, going "outside" or "into society" to work means 
entering a social milieu composed almost exclusively of young, unmarried females like themselves and, more importantly, a milieu which reinforces traditional goals of marriage and definitions of femininity consistent with parental views and those of society at large. The opportunity to earn money has not generated a "marriage-resistance movement," as happened in Guangdong (Topley, 1975). For those who live at home, marriage rather than employment is the marker of adult status. The same is true for those living in factory dormitories, in a world of adolescent friendships and sharing of knowledge that they know must be short-lived. Factory life fails to bring the young women into contact with older or married women workers or with men who are potential friends and marriage partners. The absence of trade unions under the present government further isolates each factory's workers into their own closed circle, where concern with interpersonal relations between workers in the same shop or dormitory takes precedence over class consciousness (Kung, 1979). Paradoxically, the experience of working in the factory is, for most, an intense socialization toward middleclass values and bourgeoise dreams.

\section{LIFE AT XINFENG: A MEDIUM-SIZED TEXTILE PLANT}

The factory from which my interviews were taken lies midway between the massive modern plants established by foreign capital and the small sweatshops that mark the beginning of indigenous industrialization. The Xinfeng Textile Plant (a pseudonym) is a modern plant employing almost 400 people, 320 of whom are young women who work as machine operators, checkers, packers, or group supervisors. Some other women work as clerks in the business office or as cooks and dormitory matrons. The administrative, technical, and higher managerial jobs are all held by men, most of whom live with their wives and children in company-owned apartment buildings behind the factory. The women workers are all unmarried, and virtually all of them live 
in dormitories on the factory grounds. Most are between the ages of 15 and 22.

Xinfeng is regarded locally as a progressive enterprise. Unlike many other factories, it holds to a 48-hour work week, whereas, according to government figures, $43 \%$ of women industrial workers labor between 49 and 56 hours a week, and another $15 \%$ work 57 hours or more with or without overtime pay (Taiwan Provincial Labor Force Survey and Research Institute, 1971: 50). It hires relatively few girls under the legal age (only $14 \%$ of the sample reported being hired before they were 15 ). It provides fringe benefits such as a lounge with TV and pingpong tables, the promise someday of a swimming pool and tennis courts for employees, and classes in English, sewing, and dress design. Wage levels compared favorably with other textile plants, ranging at that time from a low of $\$ 800 \mathrm{NT}$ (about US \$20) per month for new workers to a high of $\$ 1800 \mathrm{NT}$ (US \$45) for female office staff with an average income of US $\$ 28$. Wages have since risen, but so have living costs.

By any standards, the dormitories provide the most minimal comforts. They do have the advantage of being free. They are unfurnished: each girl gets floor space for the bedding she brings from home, and little more. Even the poorer peasant homes have at least bamboo bedsteads or raised sleeping platforms with thick straw mats. The smaller rooms sleep 10 girls, the larger rooms 20 , which is greater density than that found in household sleeping arrangments. However, the factory runs three shifts a day, so the rooms are never totally filled at any one time. Nor are the subsidized meals luxurious: a meal ticket, which costs about US $\$ 5$ per month entitles the holder to a meal of rice, topped with vegetables and a few snippets of meat. It is the diet of the poor.

Realistically, few of Xinfeng's workers have the option of living at home. Over $70 \%$ of the girls are drawn from the rural areas of Tainan county, and from the neighboring counties of Gaoxiong, Jiayi, Zhanghua and Pingdong. Commuting is impossible. Even for those with close family or relatives living in and around Tainan City, the dormitory is more convenient. 
Work shifts rotate every week, so that everyone would have to face the possible dangers of traveling to or from work around midnight. Further, there would be difficulties in meshing one's needed sleep time with the activities of a household on a normal schedule. The work itself is tiring, not only from the strains of standing during the eight-hour shift but also from the high noise levels in the machine rooms. The dormitories are convenient for napping during free time as well as for regular sleeping. To all these reasons, we must add the observation that most of the Xinfeng women seem to come from fairly large households. Not one in our sample was an only child, and very few were the youngest in households where older sisters might have married out and brothers gone off to do their army service. Most lived in crowded houses, with an average of 3.1 younger siblings at home and another 2.7 older siblings. Dormitory living provided an opportunity to rest that might be impossible at home, as well as relieving household congestion. And some of the girls see the dormitories as luxurious in one sense. In each corridor there are bathrooms with hot showers, flush toilets and sinks, items not found in peasant and working-class homes, as a rule.

It should also be mentioned that Xinfeng is not totally isolated. In fact, it is well within the city, a short bus ride from the downtown area with its department stores, movie houses, restaurants, and coffee shops. The immediate neighborhood is a mixture of residences and small family-operated workshops and stores, with its own secondary market area containing food stalls, cheap second-run movie houses and shops selling inexpensive clothing and daily necessities. For many of the factory girls, who come from rural villages, even this smaller market area represents urban excitement and sophistication. Although the work is tiring, and there is considerable supervision of the girls in addition to peer pressures, there is the opportunity to pick up some veneer of big city sophistication by walking around the city in one's free time, seeing a movie, or buying a snack at a sidewalk restaurant. There is also some opportunity of meeting new male friends. 
The token educational facilities offered by the factory probably give parents the feeling that they are offering their daughters an opportunity to better themselves and learn something about the society while at the same time earning wages and lessening the family's burden. Unlike the electronics factory described in Kung's articles $(1979,1976)$, few of Xinfeng's workers have a fixed work schedule which allows them to attend junior high school or senior high school classes. Those that do are already employed as accountants and clerks in the business office, keeping regular office hours. Work/study is not an option offered to ordinary workers. Still, the women themselves see their factory experience and its fringe benefits as an opportunity to learn about the world. Most seem to enjoy dormitory living and being together with their peers. Living and working at Xinfeng brings them into contact with a larger number of people, and they must learn to understand them and to adjust to those of different backgrounds and temperament. For many, one of the greatest values of their work experience as they see it is that it has made them more adept socially and has taught them to be more tolerant of differences. Coexisting smoothly with 20 roommates is after all a different problem from getting along with family members or classmates. It prepares one to face almost any eventuality, and the learning of social skills is highly valued.

\section{THE REMITTANCE OF WAGES}

Control over money was not one of the gains of the work experience. It was a privilege of $5 \%$ of my sample: remittances home from those living in the dormitories came to about $46 \%$ of gross earnings on the average, while those living at home felt obliged to turn over anywhere from $70 \%$ to $80 \%$ of their wages to their parents. There was no relationship between the number of years working at Xinfeng or elsewhere and the portion of salary remitted home. Women in their sixth or seventh year of employment were just as likely to turn over half of their earnings, or more, as were women just starting to work for wages 
outside the home. The amounts remitted seemed more to be determined by household need. It is, of course, possible that the informants exaggerated the sums sent to the household, but if so the exaggeration is uniform and suggests an expectation that working daughters should and do turn over all money beyond that needed for their own food, clothing, daily necessities, and transportation expenses.

It would be a mistake to assume, as I initially did, that this money was being put aside as savings, consciously alloted for the girl's future dowry. In some cases (about $23 \%$ of the sample) it was directed toward that end; in most cases it was not. To assure that they would enter their marital homes with a fair amount of property, the majority of the women were putting aside additional savings (around US $\$ 2.40$ to $\$ 5$ per month) for that purpose. In addition they took advantage of the sewing classes at the factory and the chance to buy good material at cost to make their own clothing. At least they would enter marriage with a respectable wardrobe. For the rest, their pocket money was spent on items of clothing that they could not produce themselves, or cosmetics, magazines, snacks to supplement the cafeteria fare, and occasional movies.

The money turned over to one's parents was seen as a repayment to them for money spent during one's first 14 or 15 years of life, but it was an indirect repayment in many cases. For a few, their earnings were the mainstay of the household or a major contribution: this was true for around $6 \%$ of the sample whose fathers were dead or incapacitated, and who had become a major source of support for mother and younger siblings. Most saw their contribution as amounting to between $20 \%$ and $40 \%$ of household cash income, and earmarked for the schooling and maintenance of younger and elder brothers during an extended education. The girls themselves, with few exceptions, had ended their own formal schooling with six years of primary school. Their brothers, however, were expected to at least finish junior high school, go on to senior high school if at all possible, and ideally continue on to college or technical training. 
Whereas in Fei's study in the 1930s daughters' remittances made it possible for households to meet their rent obligations as tenant farmers or to maintain their peasant standard of living (Fei, 1939), these remittances in Taiwan in the 1970s had become a way for households to begin the move out of peasant status. In the overall household strategy for upward mobility, teenage girls are a valuable resource. Their earning abilities, though small, make the crucial difference which enables their brothers (and sometimes a younger sister) to gain a higher education which opens the door to white-collar and professional jobs (or at least to skilled blue-collar jobs) and to good social connections.

During the $1960 \mathrm{~s}$, as mentioned earlier, participation in agriculture had begun its decline. While over two-thirds of the factory girls came from households of farmers and fisherman, in only $10 \%$ of those families had brothers followed their parents' occupation or given any indication that they were planning to do so. These are families that do not intend to continue as peasants. In $20 \%$ of the households, some or all of the brothers were also working in factories. In $45 \%$ of the households, anywhere from one to three male siblings were enrolled in senior high schools, technical schools, colleges, and universities. In $22 \%$ of the households, one or more brothers were currently working in white-collar jobs or doing highly skilled work. For those brothers doing their army service at the time of our interviews, we can assume that the same proportions would hold. Sons' education greatly outstripped that of other household members; it is worth mentioning that all but $10 \%$ of the mothers of the factory girls were illiterate, as were over half of the fathers, and less than $6 \%$ of the fathers had gone beyond primary schooling.

Given parental educational level and experience, it is not surprising that they might see themselves as already having done the best they could for their daughters by allowing them to finish primary school and then sending them off to work in a factory until they married. The sisters of most of the sample were either working at Xinfeng or similar plants (55\%), or helping 
out at home with the care of younger siblings, farm work, or management of a small family business. In only $20 \%$ of households where there were unmarried girls over the age of 15 were any of them attending school. Taiwan still is very traditional: the expectation is that sons will carry the responsibility of caring for parents in their old age, while daughters are "water spilled on the ground," a waste of investment after a certain point. If a daughter cannot be useful staying at home to help out then she might as well begin working when she completes her primary education. It is sons who are the hope for one's future, and it is for sons that sacrifices should be made. Nor do girls seem to resent working on their brothers' behalf; it is their family duty to do so.

This pattern in which young women join the labor force in order to advance their brothers' careers is not unique to Taiwan, of course. One is reminded of immigrant girls working in the sweatshops of New York at the turn of the century, while their brothers studied to be doctors and lawyers at City College. The pattern may also raise some of the same problems when it comes to marriage. As the men move up the social ladder via education, they develop expectations of marrying women with educations somewhat closer to their own, from families of higher status or greater respectability. A university graduate wants a wife whose background is commensurate with his newly won social standing, not a poorly educated factory hand, similar to the girls he would have married had he never gained an education.

\section{PLANNING AND HOPING FOR THE FUTURE}

As Kung would agree, factory work has little glamour or prestige, though it is preferable to farm labor. It is a poor "fate" or a "bitter lot," even though it pays better than being a servant and is more interesting and prestigious than helping out at home. Given other options, only $15 \%$ of the young women in my sample said they would want to continue working at the same 
job. The ideal job, in the eyes of $42 \%$, was tailoring work, a skill which many were learning in their spare time. For others, a job as a store clerk seemed preferable, or a job in some other section of the factory where the work was lighter. And some wished for office and clerical jobs, had they the requisite education level. If they had had more control over their lives they would have at least finished junior high school; they would have sought white-collar jobs for themselves. A sizeable number saw the factory evening classes as a way out: they might someday open a small tailor shop, though it was not clear where the capital for this would come from.

But because there is no way for most of them to advance their formal education or open a shop, it is marriage which is regarded as the realistic, possible route to upward mobility for themselves. The wishes and expectations that these young women hold about marriage differ little from those of their more fortunate middle-class and upper-class sisters. They dream of marrying someone who is a government official, a lawyer, doctor, teacher, businessman or white-collar worker. They dream of marrying what their brothers hope to become. Relatively few envision their future as marriage to a factory worker or the owner of a small shop. None see themselves repeating their mothers' lives, being farm-wives.

Their dreams are not totally out of line with reality. Far more peasant and working-class sons receive education than do daughters, and given the fact that in the society overall women hold only a third of the places in senior high schools and colleges it is fairly obvious that most of these men will not be able to marry unless they marry "down" educationally. Some of them will marry less educated factory workers. Given the persistence of male chauvinist thinking in Taiwan, there will always be some educated men who choose a less educated wife on the theory that she will make a better mother and a more docile spouse. It is rare, but not unknown in Taiwan, to meet men with graduate degrees and semiliterate wives, even among the younger generation. Xinfeng's girls have at least completed primary school, they are literate (highly so, in comparison 
to their mothers), and the combination of dormitory living and exposure to urban life has given them some self-assurance, social skills, and sophistication in manner and dress which marks them off from peasant girls who have remained at home in their "green years." Indeed, when dressed up for their day off or for a walk in their free hours, they are not that easily distinguished from their middle-class counterparts.

For the time being, though, marriage is still something off in the future and undecided in any way for most of the women. No more than $5 \%$ of them admitted to being formally engaged (usually through introductions and arrangements made by their parents, family friends, older brothers, and matchmakers), though I suspect the numbers are higher. Another $9 \%$ said that matches had been suggested to them by their parents, but they had refused. This is an important aspect of control over their own lives, one which more girls may take in coming years.

Some, still a minority, seek control over their futures by maintaining friendships with young men: about one-fourth of the sample claimed to have a "special" male friend. In most cases it was someone introduced through family connections and friends. In a few cases, it was a pen pal found through a magazine advertisement. In even fewer cases, it was someone met on their own initiative. One of the older girls told us proudly that she was soon to be married to a government worker she she had met at the city swimming pool. Most of the male friends, however, whether met through introduction or one's own efforts, were described as factory workers, sales clerks, artisans, or soldiers, not as the rising professionals of their dreams, and the girls themselves were mostly over 20 , nearing marriage age. Younger girls did not have boyfriends, generally.

Their envisioned marriages are middle class in content. Most expect that they will drop out of the labor force when they marry: few desire to keep working past the first pregnancy, and given the realities of the job market, there is little chance that they can keep working. They look forward to being full-time housewives and mothers, unlike most of their own mothers whose domestic roles included farm work, petty trade, or assistance 
in the family small business. They look forward to having children. Despite recent government backed campaigns for family planning, most of them expressed a desire for two or three sons and two daughters. Married life itself was visualized within the framework of a modern (nuclear) family: only $20 \%$ expressed any positive feelings toward living in an extended or joint family with husband's parents and/or married brothers. Their views of married life have been strongly influenced by the middle-class model presented in the mass media: not only television, to which they have easy access, but also the novels, short-story magazines, movie magazines, and women's magazines which circulate in the dormitories and enjoy enormous popularity. Six years of education may not seem like very much, but this is a group that is keeping its literacy alive. Some $40 \%$ of the sample reported the reading of popular fiction and magazines as their first choice of a leisure time activity, and could list two or three magazines that they read regularly as well as current popular novels that had appealed to them.

Even if one's real life husband may fall short of the mark, in terms of ideal expectations, there is still faith that a rise in social status will come through one's children. More than half of the sample were hopeful that their sons would graduate from college: some even envision them going on to do advanced graduate studies in America (a common theme in popular literature). Aspirations for daughters are more modest, reflecting the lower levels of expected achievement for women in the society generally, but there is the expectation that one's daughters will continue past primary school and complete a senior high school education (and 27\% thought that their daughters would go on to college). Daughters would also have careers commensurate with their education: they would be schoolteachers and nurses. Still, while none of the girls visualized their sons going into anything other than white-collar and professional jobs, there were some who saw nothing out of place in expecting their daughters to work in factories prior to marriage. 


\section{FILIAL PROLETARIANS}

The envisioned rise into the middle class does not and should not imply any serious conflict with parental values and disciplines. The parents of the peasantry and working class share in the dream right now: they are investing heavily in the education of their sons and encouraging their daughters to sacrifice for those sons. Going out to work in the factories is a family strategy, not an individual attempt to shape one's life. Virtually all of the young women had entered the work force with parental support and encouragement, in order to contribute to household finances. Where opposition to the job had been voiced by parents, it was in terms of disapproval of the general working conditions at Xinfeng and/or the belief that the daughter could find a better job elsewhere. Only $8 \%$ of the women we interviewed indicated that one or both parents disapproved of their working and wanted them at home, or working nearer to home.

Moreover, very few of the women believed that they would follow through on major decisions such as going to Taibei to work if they met with parental opposition. Most took pride in being obedient and loving daughters who followed parental advice and plans - both parents and daughters in this instance shared the hope that the girl would marry a man with more education than herself and who held a respectable and decently paid job. There are some areas of conflict, of course, over such things as use of cosmetics, new fashions in dress, recreational activities, and choice of closest friends. Here, there are some attempts at deception, keeping certain things hidden from parents. It can be easily done because most of the young women do not try to commute home every week: it is too expensive and tiring. By not living at home, most of these women are at a disadvantage in influencing family decisions such as major purchases or educational or vocational plans for siblings. And on personal or minor aspects of autonomy, such as dress or choice of friends, the physical distance enables them to avoid direct confrontation with family opinion. 
Most of the girls still feel very close to household members and identify with them. Here and there, one finds mavericks who insist that they are unique and different from others in their family, that they move in a different mental world or that no one at home is capable of understanding them: it is difficult to attribute this to the fact that they are working. Rather, they tend to be the young women who have escaped from home, sometimes over parental opposition, because factory life enables them to survive outside of the family milieu. In earlier times they would have sat at home being miserable, or perhaps resorted to suicide. They are critical of their own families, or even ashamed of them, but they do not reject family life per se.

Given the continuation of close family ties, and the lack of any real financial independence or chance to gain the training that would make independence possible, it is not surprising that women in the sample tended to look toward their parents and other family members to arrange their eventual marriages. Despite exposure to new ideas through the media, it was a clear minority (13\%) who thought that women should arrange their own marriages: this was an important decision which was best left to one's elders. One factor at work here may be their social isolation during the working week. Unlike college students or office workers, there is little opportunity to meet young men and gradually form friendships with them in this kind of work setting. In the end, the girls rely still on parents and kin networks for assistance. Though they admire the idea of choosing one's spouse and the idea of a marriage based on love, most of them are unable to carry out this ideal.

Moreover, the experience of working has not made for drastic changes in the perception of women's abilities and roles in the society at large. These are still girls who are in strong agreement with such traditional sayings as "a daughter follows her father, a wife follows her husband, a widow follows her son." The superiority of men to women is unquestioned by most of these young women. Less than $10 \%$ voiced disagreement with the cliche that "men's place is outside the home, women's place is inside." Indeed, how could it be otherwise when the models one has 
of working women are either unmarried girls or women in the poorer segments of the society and women of the peasant class? And even with the opening of education to girls, the sample was split down the middle in its agreement or disagreement with the Confucian maxim that "a woman's virtue lies in having no talents."

The shift of opinion on this last item merits some further commentary. As mentioned before, factory work carries little prestige if any, and these working girls admit to feelings of inferiority when they compare themselves to girls who have been fortunate enough to continue their schooling. Student life is glamorized in Taiwan. College days particularly are seen as a happy and carefree time leading to an even brighter future. There is envy and regret in many cases over the fact that one's family circumstance did not allow for a prolongation of the student life. Middle-class girls can continue their educations even if they are not brilliant students: their families will hire tutors for them; their parents will pay for private schools if they fail to pass the examinations into government schools. But for many factory women, even an outstanding primary school performance would still have made no difference in determining their future lives. They would still have been encouraged into the work force at the age of 14 . So there is some comfort in repeating the belief that women do not need advanced education or the kinds of skill training available to men, even though they envy the prestige that higher education brings, or the chance for a better job.

The major shift from traditional views of women, as suggested earlier, is on the question of the usefulness of daughters compared to sons. There is no question now but that daughters are of use to their families. In many households, daughters are at some point in the family cycle more useful than are their student brothers, or the brothers who are soldiers or unpaid craft apprentices. They can act out male roles of filiality and support which were closed to them in the past. There are even some who can visualize themselves as being useful economically for the first year or two of their married life: one-fourth of the 
sample expressed the desire to continue work even after marriage, but only up to the point where they have children. Within the limits imposed by the structuring of the labor force, these women seem to question the traditional hard-line view of female inequality and women as passive dependents on the men in their lives. One wonders, of course, whether such feelings might not have been present in more traditional times, when filial daughters labored at home to produce silk and cotton cloth for the market. Perhaps the point to be gained here is that such feelings can be more clearly articulated when the money comes to the girl from the factory, for her to disperse, rather than going directly into the hands of the male household head. Nowadays, there is the illusion of choice about how one's earnings are to be allocated, whereas in the past there was no choice and women's contributions to the household economy were masked, or denied. The girl might not have known how much her labor was worth. Today, she has a clearer idea of the household total, and her contribution to that total. It is irrelevant that the term of employment is only temporary (when one is young, seven or eight years is a long time), or that the wages of women workers are half or less than half the wages of male workers.

Economic usefulness to one's family does not lead to autonomous decisions or independence for most girls. As suggested earlier, few of the girls under the age of 20 yet have a special male friend. Even for the elder girls, for whom marriage is soon in the offing, their relationships to boys are usually initiated and approved by their family, and the young man is then welcome to visit at their house. Dating involves an occasional walk, a movie, a snack somewhere, or going out with friends. One does not "date" more than one boy-dating is a serious matter. Sexual activity prior to marriage is strongly frowned on: I have no way of judging whether this last is rhetoric or reality, but given the living circumstances of young people, it is unlikely that there is opportunity for premarital sexual experimentation. 
One must assume that the sample of women from Xinfeng resembles many other young factory women elsewhere in Taiwan. They are filial proletarians with strong family ties. The general political atmosphere in Taiwan encourages familism, and a second-place status for women (Diamond, 1975); and young working women do not appear to question seriously the status quo. If pushed to the brink they might resist an undesired arranged marriage by withholding remittances and/or appealing to their families' good will. In the Taiwan setting, they are encouraged toward identification with middle-class lifestyles and values, and many of them will take little from their factory days into their future lives except for the social skills and some of the friendships that they have gained there.

The one thing that factory work experience clearly does not do for either sex is heighten class consciousness and political awareness. Lydia Kung suggests that whatever resentments or negative feelings that arise from the work situation itself tend to be focused on interpersonal relationships: the social problems of dealing with group supervisors or foremen, as well as the social problems of relating to work group peers and dormitory mates (Kung, 1979).

If we look back to the labor movement on the mainland of China during the 1920s and 1930s, we find that large numbers of women were similarly employed in light industry at wages markedly inferior to those accorded to male workers. Many of the female workers were indeed children (i.e., under the age of 12), and many, if not most, were recruited under a labor contract system in which agents recruited girls from the countryside, paid their families a small sum, allotted some funds for food and shelter, and effectively pocketed half or more of the women's actual wages, which were quite low to start with (Wales, 1945; Chesneaux, 1968). In Shanghai, the most industrialized area at that time, women workers made up more than half of the labor force. They were preferred because of their docility and their willingness to accept low wages. Most, though by no means 
all, of the major labor disturbances that occurred involved male workers, who had been effectively organized into trade unions and politicized. Women workers in Shanghai were $52 \%$ of the labor force, but only $15 \%$ of union membership in the late 1920 s, before the Guomindang abolished real labor organizations and forbade strikes (Mao, 1928).

Still, there were brief periods of labor militancy on the part of women workers: a major strike in 1923 by cotton mill and cigarette factory women in which 10,000 women participated, for example, or the series of strikes in the tobacco industry, which was staffed almost entirely by women workers (Wales, 1945: 195-198). And although many of these were short-lived and limited to only one factory, the number of strikes by women textile workers between 1919 and 1926 was not only relatively but absolutely greater than in any other industry (Chesneaux, 1968: 379).

However, many of these early strikes in the Chinese labor movement were over issues that have been resolved by the "paternalism" of factory management in Taiwan today, whether it be foreign-owned enterprises or local plants. There is no need to strike over the issue of corporal punishment, absence of a lunch period or washroom facilities, kickbacks of pay to foremen or hiring agents, and so on. Sleeping space is provided in dormitories rather than under the machines, and the 12- or 14-hour day is a thing of the past. Most modern plants consciously try to provide a few "frills" and to show the goodwill of management toward its employees. Some factories even make it possible for the workers to study toward middle-school degrees by having fixed work times, and there is the opportunity there for upward occupational and social mobility and perhaps greater independence. As for increased political awareness, we can only point out that male workers are equally unorganized and politically silent, though their income needs are greater. The temporary nature of women's employment makes it unlikely that they will risk losing present day gains by engaging in what the government regards as illegal activity. For the time being, at least, the bettering of their futures lies in making the ideal 
middle-class marriage, and it is there that their concerns are focused. Given the relative scarcity of educated women as potential partners for upwardly mobile peasant males, their dreams are not out of line with reality.

\section{NOTE}

1. In this study, 134 women (roughly a third of the work force in a medium-size factory) were interviewed with a lengthy questionnaire covering family background, education, reasons for working, monthly budgets, dating and engagement, marriage plans, areas of controversy with parents, relations with parents and siblings, workplace social relations, use of leisure time, future job aspirations and plans, marriage and future family expectations, and degree of consensus with proverbial or traditional sayings about women. Some of the information presented here comes also from discussions with factory managers, dormitory matrons, and observations within the factory.

\section{REFERENCES}

CHESNEAUX, JEAN (1968) The Chinese Labor Movement, 1919-1927. Stanford, CA: Stanford Univ. Press.

DIAMOND, N. (1975) “Women under Kuomintang rule." Modern China 1, I (January): 3-45.

FEI, HSIAO-TUNG (1939) Peasant Life in China. London: Routledge and Kegan Paul.

KUNG, L. (1979) "Perceptions of work among factory women in Taiwan," in H. Rohsenow and E. Ahern (eds.) The Anthropology of Chinese Society in Taiwan, (forthcoming) Stanford: Stanford Univ. Press.

- (1976) "Factory work and women in Taiwan: changes in self-image and status." Signs 2,1 (Autumn): 35-58.

LAMSON, H. D. (1931) "The effect of ind ustrialization upon village livelihood." Chinese Economic J. 9, 4 (October): 1025-1082.

LANG, OLGA (1946) Chinese Family and Society. New Haven: Yale Univ. Press.

MAO, CHI-CHUN (1928) "The unemployment problem of the municipality of Shanghai." Chinese Economic J. 3, 5 (November): 918-925.

Taiwan Provincial Labor Force Survey and Research Institute (1972) Quarterly Report on the Labor Force Survey in Taiwan, Republic of China (January).

TOPLEY, M. (1975) "Marriage resistance in rural Kwangtung," pp. 67-88 in M. Wolf and R. Witke (eds.) Women in Chinese Society. Stanford, CA: Stanford Univ. Press.

WALES, NYM (1945) The Chinese Labor Movement. New York: John Day. 


\section{Appendix}

\section{Some Sample Case Histories}

1. She is now 19 years old, and has been working on the weaving machines at Xinfeng for the past year. Before that she worked for three years at a smaller factory closer to her home in rural Tainan county. Her mother does much of the work on the family's small farm, while her father works as a small merchant. She estimates that without her help the household income would be only NT \$3,000 a month. She contribues NT $\$ 800$ of her salary to the household, and keeps the remaining NT $\$ 500$ for her own use, which includes her NT $\$ 180$ for a meal ticket at the factory, and the pocket money she needs for clothing and odds and ends. Her main reason for working is family circumstances plus her desire to have some money in hand for her own use. Besides, she prefers being at a factory with other girls to helping her mother on the farm. There is one older sister, who is now married and gone from the household. Her teenage brother is a middleschool student. There is no pressure on her to get married or even engaged: the family has not yet suggested any engagement plans for her, and none of the money that she is remitting home is being set aside for her dowry. She is basically a filial daughter, close to her parents emotionally and glad to be useful to them and to her younger brother. The one point on which she has gone against parental wishes is in transferring to work at Xinfeng, where she has no choice but to live in the dormitory. Her parents would prefer that she continued living at home, even though she now gets higher wages than what she earned before.

2. She is 20 , and has been working steadily at Xinfeng for the past five years. Despite this long tenure, her earnings are low compared to other girls at her level but she does not seem to mind. Nor does she mind that all but $\$ 140$ of her earnings are turned over directly to her parents. She lives at home, under parental supervision and that of her four elder brothers and two sisters-in-law. Though she says that she is working merely to help pass the time until she marries, the heavy family claims on her income suggest otherwise. Her family is strongly opposed to her living in the dormitories, and similarly opposed to her having male friends. As yet, they have not taken any steps to introduce her to a suitable marriage partner or arrange an engagement. Cut off from the social life of the dormitories, she spends most 
of her free time either sleeping or reading enormous amounts of fiction. Though she has only six years of formal education, she is fond of romantic modern novels and short story magazines. She sees herself as less socially adept, less lively and outgoing than most of her workmates and is somewhat ill at ease with them.

3. She has been working at Xinfeng for a year and a half, and has just turned 16. Her parents, who are peasants, were eager that she follow her older sister to the factory. The two girls are very close, and share the same dormitory room: she is grateful for her sister's presence because as she says, she still feels shy with some of the other girls in the dorm. As a relatively new worker she earns little more than NT $\$ 800$ a month, but she dutifully sends half of it home. The family has three younger daughters, and one son on whom the hopes of the future seem to be fixed: he is the only one attending middle school, though perhaps one of the younger girls may also have that option. Unlike most of her peers, she thinks she would enjoy marrying into a large family because of the company that it would provide during the day, though she would want it to be an urban household, perhaps one with a large family business.

4. She is also 16 , and second generation working class: both her father and her elder brother work in factories in Tainan. Her second eldest brother is a senior high school student. The family never considered further schooling for her. She began work when she was 13, and entered Xinfeng when she was 15 as an experienced worker. She earns close to NT $\$ 1,100$ a month and sends NT $\$ 480$ of it home. Her pocket money goes quickly on clothing and cosmetics, of which her parents clearly disapprove. She also spends a more than usual amount of time at the movies, and is an avid reader of movie magazines and fashion magazines. Yet despite this, she is more grounded in reality than some of her peers: she is one of the few who does not have fantasies that she will marry a college graduate. Indeed, she says she would be satisfied to marry someone with a steady job of any sort, and to see her children go on to high school so that they in their time can find work to do what they will really enjoy.

5. It is hard to tell if she is a disappointment or a blessing to her family. Her father is a rural schoolteacher, and her elder sister and four younger brothers and sisters are in school. She, on the other hand, went directly from primary school to work in a textile factory for two years, and then transferred to Xinfeng two years ago. She is 
now 17. Her earnings are high: over NT $\$ 1600$ a month, of which half is sent home to assist the family. She feels that she is working to please her parents and to enable her younger siblings to study. At the same time she says that her father wanted her to continue in school and is displeased with her, that her reason for working is that she did not enjoy being a student. Despite her disclaimers of being intellectually oriented, she reads widely and more seriously than most of her dorm mates, and remarks that she feels inferior to girls who have gone on in their formal schooling. Despite her father being a teacher, she would prefer to marry someone in business or an accountant, and she currently has a "boyfriend" who is a pen pal. They have yet to meet face to face.

6. She is from a large rural family, with both parents totally illiterate. Now 17, she has been working for almost two years at Xinfeng, after a brief stint as a salesgirl. Her earnings are still beginner's wages, and almost half of it is remitted home to aid in the support of four younger siblings and a brother who is a college student. She reads little except for women's magazines, and watches television a lot. In her dreams of the future, she wants to marry a college graduate who has a secure civil service job. Further, she hopes that her sons will study abroad and come home with $\mathrm{Ph} . \mathrm{D}$. degrees or become medical doctors, and her daughters will all successfully graduate from college and become schoolteachers. Of all the household members, she is closest to and most admiring of her elder brother, perhaps also hopeful that he will be able to aid her in securing her own future as she dreams of it.

Norma Diamond is Professor of Anthropolog! at the University of Michigan. She is concerned with questions of peasant econom!: social change. and the role of women. 